\title{
Sustainability Reporting in Cambodia: The Hidden Champion of ASEAN Countries
}

\author{
Boris Miethlich
}

\begin{abstract}
Cambodia has undergone enormous development in recent decades. The government of Cambodia wants to secure and further promote growth through a consistent concentration in its national development strategy on socioeconomic inclusion and environmental sustainability. While some countries have been discussing sustainable development and corporate social responsibility (CSR) for several decades, CSR in Cambodia is a relatively new concept. For the sustainable development of the country and an increase in the prosperity of society, there is a need for interaction between the state and companies. However, sustainable development can only be achieved with the active participation of companies. Simultaneously, companies can generate additional competitive advantages from CSR. However, the prerequisite for this is that stakeholders are aware of CSR. Accordingly, sustainability reporting is becoming increasingly important as an instrument for CSR communication and achieving competitive advantages. However, the dissemination and use of sustainability reporting in Cambodian companies have not yet been investigated. The aim of this study is, therefore, to present and analyse the current situation of sustainability reporting in Cambodia. The expected results are indications of whether and in what way sustainable development and its reporting is a concern of Cambodian companies. The data basis for the study is a literature search, an internet search and the Sustainability Disclosure Database of the Global Reporting Initiative (GRI). The results show that compared to the other Association of Southeast Asian Nations (ASEAN) countries, Cambodia is fourth last in terms of sustainability reporting. However, if the figures are put in relation to the gross domestic product (GDP) based on purchasing power parity (PPP), Cambodia ranks first. Cambodia can, therefore, be seen today as a hidden champion of sustainability reporting among the ASEAN countries and, thus, also as a role model for other developing countries.
\end{abstract}

Keywords: Cambodia, CSR, sustainable development, sustainability reporting.

\section{INTRODUCTION}

In recent decades, Cambodia has undergone enormous development and has made great strides in restoring the country's social and economic infrastructure, human resources, and the identity of the Khmer people [1]. Accordingly, the government of Cambodia today also focuses on its national strategy for sustainable development and increasing national competitiveness by stimulating corporate social responsibility (CSR) performance [2]. With its consistent concentration in national planning and

Revised Manuscript Received on October 25, 2019

Boris Miethlich, Graduate School, IIC University of Technology, Phnom Penh, Kingdom of Cambodia. Email: boris.miethlich@gmail.com policy-making framework on socioeconomic inclusion and environmental sustainability, the government intends to develop the nation further and thus secure its economic growth to date as well as its rapid speed. A national strategic framework that includes the potential contribution of enterprises and tries to reconcile CSR with development goals allows governments to derive significant developmental benefits from CSR [2]. Cambodia's development strategy is based on the United Nation's (UN's) Sustainable Development Goals (SDGs) and addresses all stakeholders to contribute to the country's prioritised sustainable development, including the private sector, academia, and civil society. The aim is for the nation to rise to an upper-middle income country by 2030 and to a high-income country by 2050 [1].

While some countries have been discussing sustainable development and CSR for several decades, CSR in Cambodia is a relatively new concept. After the introduction of the market economy in Cambodia in 1993, an enormous economic upswing began, which lasted almost continuously until 2008 and then suffered a significant slump in 2009 with the global financial crisis. The economy was already recovering rapidly in 2010 and had been growing continuously since then at around $7 \%$ per year. This makes Cambodia one of the fastest-growing economies in the world [3]. Cambodia's economy is strongly export-oriented, and more than half of its investments come from abroad. Accordingly, Cambodia's economic growth is closely linked to the development of the world market. The most important sectors are textiles, construction, tourism and agriculture [4]. Apart from economic growth, Cambodia is also developing rapidly. Measured by the Human Development Index (HDI) of the UN, the improvement was the largest in the region. Nevertheless, living standards still lag behind those of neighbouring countries [5]. The majority of the population lives in rural areas and, unlike the urban population, is much more often affected by poverty. Economic and social development that includes rural areas and the population is still necessary [6]. Cambodia exported goods worth $60 \%$ of gross domestic product (GDP) in 2017. In the manufacturing sector, clothing and shoes account for the largest share of these goods, and parts for the automotive industry and electronics are increasingly being manufactured and exported. Strong growth has been achieved in the services sector for several years, driven in particular by increasing domestic demand. Tourism, retail/wholesale, and real estate sectors provide the most employment and contribute significantly and increasingly

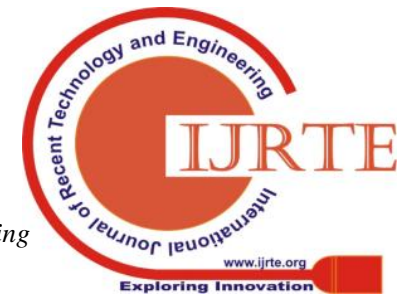


to economic performance [1]. With increasing awareness of CSR, the implementation of CSR and ensuring sustainable development throughout the value chain is becoming increasingly important for companies. This also means for suppliers that CSR can be used to differentiate and win new customers and thus provide a competitive advantage [7], [8]. CSR has great potential for strengthening Cambodia's competitiveness, not only to attract foreign investment but also to improve the business environment. CSR is a relatively new concept in Cambodia. Most companies and their stakeholders are not aware of the strategic importance of CSR in generating competitive advantage. Accordingly, CSR in Cambodia must continue to be actively promoted, and companies must be made aware of it [6]. Corporate commitment to sustainable development can make a significant contribution to raising living standards, further reducing the poverty rate and strengthening economic competitiveness.

Companies play an important role in the sustainable development of a country. Companies should understand their role in a country in the same way as a citizen and deal with rights and obligations in the same way. Citizenship not only entails rights but also obligations and responsibilities for a country and its society [9]. The population increasingly expects companies to assume social responsibilities [10]. For companies today, the question is, therefore, no longer for or against an altruistic socially responsible commitment, but how the sustainable development of the company and society can be promoted [11]. In the globalised economy, the assumption of appropriate social responsibility has become a social necessity. Companies must ensure that their relationships and impact on society are so effective as to maximise the positive effects and minimise the negative ones. The activities of a company have a direct as well as an indirect economic, ecological and social impact on all those associated with the company [9]. Sustainable development can create joint added value for companies and society while simultaneously increasing prosperity. Since companies and the society in which they operate interact, this, in turn, has a positive influence on the company [12]. Sustainable development and an increase in society's prosperity require interaction between the state and companies. The state can define development goals and make its contribution. Ultimately, however, sustainable development can only be achieved with the active participation and contribution of the companies themselves.

Nevertheless, many companies are not aware of the content and impact of CSR [13], [14]. But even public perception can hardly grasp the implementation of CSR in a company [15]. It has long been recognised in business practice that a socially responsible reputation has a positive influence on business success [13], [16]. Although more and more companies are providing separate reports on CSR activities and the achievement of social and environmental goals, the information is often not specific enough to be of value [7]. Standardised and consistent reporting is important to monitor and manage the effectiveness of CSR activities [8], [17]. For the adaptation and control of CSR and CSR measures in companies, a variety of instruments already exist, such as corporate guidelines, international standards, certifications, guidelines, and guidelines for sustainability reporting or comprehensive management systems [18], [19]. The sustainability reporting framework of the Global Reporting Initiative (GRI) is the most widely used and widely recognised. It is used by organisations of various types and sizes [6], [20]. For example, $95 \%$ of the 250 world's largest companies report on their sustainability performance, $89 \%$ are using CSR guidance or frameworks for their reporting, $75 \%$ rely on the GRI framework for their sustainability reporting [20]-[21]. Sustainability reporting is an important tool of CSR communication to highlight efforts and measures to promote sustainable development [20], [22] and is becoming increasingly widespread [20]. Sustainability and CSR reporting can also be used to measure a company's commitment to sustainable development and make it transparent. The reporting serves internally as a basis for monitoring the success and further development of CSR initiatives and externally for informing stakeholders about CSR performance [22], [23]. Awareness of CSR activities among stakeholders is a prerequisite for achieving benefits from them [13], [24]. Accordingly, sustainability reporting assumes an important function for companies to generate additional competitive advantages from CSR commitments [13]. Companies can only generate additional competitive advantages from CSR if efforts are communicated and stakeholders are aware of them.

The dissemination and use of sustainability reporting in Cambodian companies have not yet been investigated. Due to the many advantages that a company can gain from such a commitment, it can be assumed that a company that is committed to social concerns and contributes to sustainable development communicates this in some form and makes it visible. The aim of this study is, therefore, to present and analyse the current situation of sustainability reporting by companies in Cambodia. The expected results are indications of whether and in what way sustainable development or CSR and its reporting is a concern of Cambodian companies.

\section{METHODS}

The study is based on a search in the GRI Sustainability Disclosure Database [25]. The data is evaluated using descriptive statistics. In addition, the scientific databases 'Scopus' and 'Web of Science' (fields: Title, abstract, keywords), with the search query '(csr OR sustainability) AND (report OR reporting) AND (Cambodia)', as well as the internet with the Google Search engine (in English and Khmer) with the search query '(csr OR sustainability) AND (report OR reporting) AND (Cambodia) site:.kh' were searched for sustainability reporting in Cambodia. For comparison with other countries, GDP based on purchasing power parity (PPP) and population data from the World Bank World Development Indicators (WDI) [3] and International Monetary Fund (IMF) World Economic Outlook Database [26] were used. 


\section{RESULTS}

The analysis of data from the GRI Sustainability Disclosure Database shows that sustainability reporting in Cambodia has increased continuously over the past ten years (see Figure 1). What is striking is that companies in the financial sector, in particular, have always published sustainability reports. Companies in the financial sector also account for the largest share of sustainability reporting, followed by the tourism and leisure industry and, more recently, telecommunications. On the other hand, companies in the manufacturing sector do not appear to have sustainability reporting.

\section{Reports per Year}

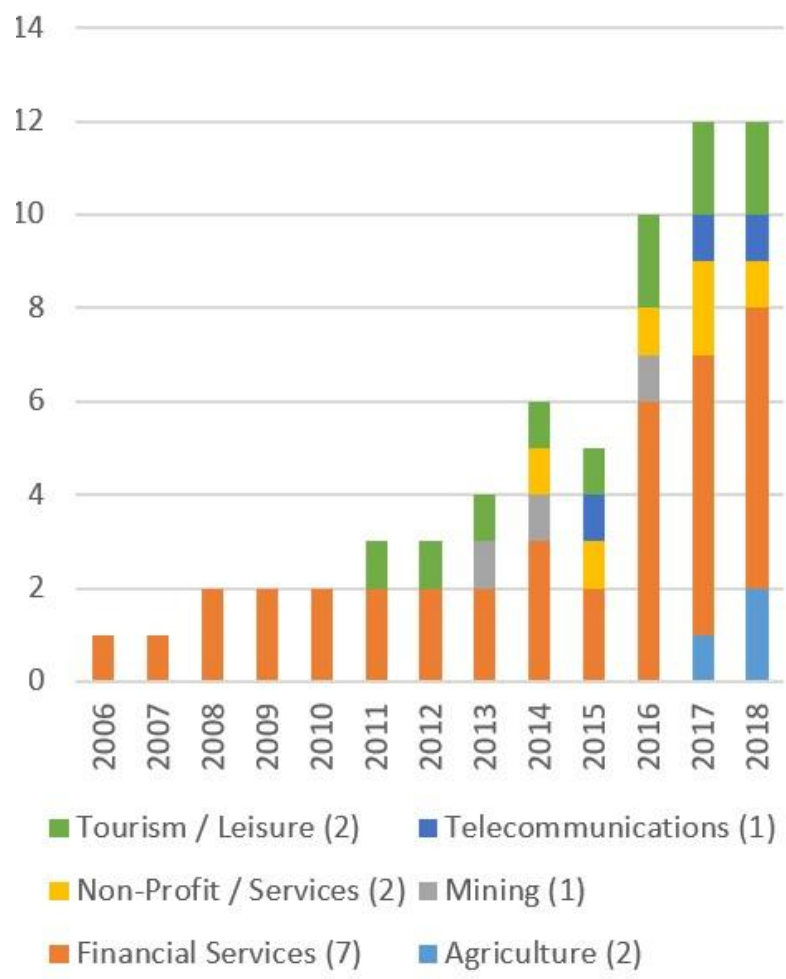

Fig. 1.Reports per year.

Sustainability reporting is largely based on large companies in Cambodia (see Figure 2). The large companies in Cambodia were the first to start sustainability reporting. Astonishingly, small- and medium-sized enterprises (SMEs) have been increasingly disclosing and communicating their sustainability efforts for some years now. Multinational companies, on the other hand, only started to do so a few years ago.

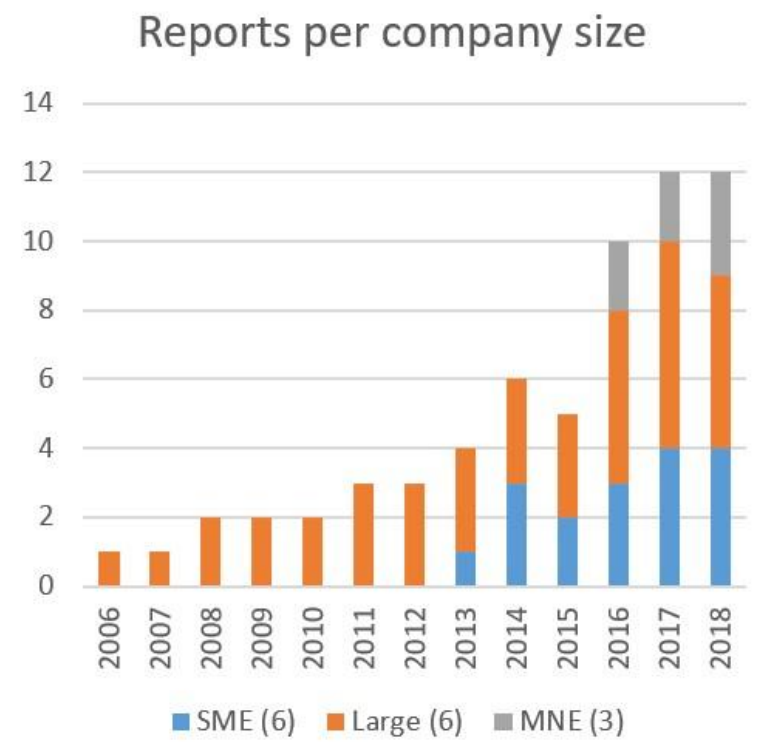

Fig. 2.Reports per company size.

Compared to the ASEAN countries, Cambodia is in fourth last position in sustainability reporting, ahead of Brunei Darussalam, Laos, and Myanmar (see Figure 3).

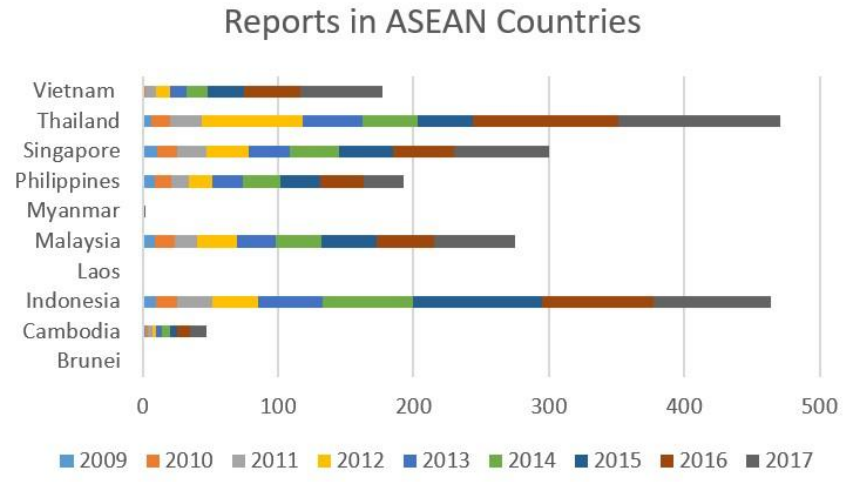

Fig. 3.Reports ins ASEAN countries.

However, Cambodia ranks fourth in terms of population in relation to the other Association of Southeast Asian Nations (ASEAN) countries, after Singapore, Malaysia, and Thailand (see Table 1).

Table- I: Ratio of reports to population

\begin{tabular}{|l|l|r|}
\hline \multicolumn{3}{|c|}{ Ratio of reports to population } \\
\hline Rank & \multicolumn{1}{|c|}{ Country } & $\begin{array}{c}\text { Population } \\
(2018 ; \text { in Mio. })\end{array}$ \\
\hline 1 & Singapore & 5,6 \\
\hline 2 & Malaysia & 32,5 \\
\hline 3 & Thailand & 66,2 \\
\hline 4 & Cambodia & 15,8 \\
\hline 5 & Vietnam & 94,7 \\
\hline 6 & Indonesia & 265,2 \\
\hline 7 & Philippines & 107,0 \\
\hline 8 & Myanmar & 53,9 \\
\hline
\end{tabular}


In relation to GDP (PPP), Cambodia is in the first place, even ahead of Singapore (see Table 2).

Table- II: Ratio of reports to GDP (PPP)

\begin{tabular}{|l|l|r|}
\hline \multicolumn{3}{|c|}{ Ratio of reports to GDP (PPP) } \\
\hline Rank & \multicolumn{1}{|c|}{ Country } & $\begin{array}{c}\text { GDP }(\text { PPP }) \\
(2018 ; \text { in Mio. Int } \mathbf{l} \text { \$) }\end{array}$ \\
\hline 1 & Cambodia & 70662 \\
\hline 2 & Singapore & 571687 \\
\hline 3 & Thailand & 1320876 \\
\hline 4 & Vietnam & 710552 \\
\hline 5 & Malaysia & 1014018 \\
\hline 6 & Philippines & 953288 \\
\hline 7 & Indonesia & 3495941 \\
\hline 8 & Myanmar & 328974 \\
\hline
\end{tabular}

No scientific publications or data on sustainability reporting in Cambodia could be found in the scientific databases 'Scopus' and 'Web of Science'. An additional internet search for Cambodian companies that carry out sustainability reporting yielded only a little additional information. The 15 additionally identified companies predominantly keep their sustainability reporting more or less up-to-date and comprehensive on their websites. Of these, only four are companies that have integrated their sustainability reporting into the annual report but do not follow the GRI framework. Of the 15 companies, 12 are from the financial services sector, two are telecommunications providers, and one is from the construction industry. Multinational enterprises (MNEs) with branches or suppliers in Cambodia usually maintain an international reporting system, which usually only deals with activities in Cambodia in general and not specifically. Otherwise, some companies could be identified that refer to CSR activities and self-commitments on their website or annual reports, but do not disclose these in detail, and therefore, the commitment, development, and success are not traceable.

\section{DISCUSSION}

The scientific citation and publication databases do not contain any publications or data on this topic. The results of the internet research provided hardly any additional information, but the data supported the results from the analysis of the GRI Sustainability Disclosure Database. These results show that sustainability reporting by companies in Cambodia has increased continuously over the last ten years. The largest share is accounted for by companies in the financial sector, followed by the tourism and leisure sector and the telecommunications sector. The companies in the manufacturing sector, most of which are suppliers, do not appear to have sustainability reporting. In terms of company size, it is mainly large companies that carry out sustainability reporting. What is surprising, however, is that SMEs is increasingly disclosing and communicating its commitment to sustainable development. MNEs, on the other hand, only started doing so a few years ago and still make up the smallest share. Compared with the other ASEAN countries, Cambodia ranks fourth last in terms of sustainability reporting. However, if the figures are put in relation to GDP (PPP), Cambodia is in the first place.

There is no national standard for CSR or sustainability reporting for companies in Cambodia. For example, the majority of companies that report on sustainability do so based on the GRI framework. Despite the efforts of the Cambodian government to promote sustainable development, only a small proportion of companies in the country communicate their CSR and sustainable development efforts. This is not unusual in the sense that companies are unable to provide sustainability reporting due to the lack of CSR data or available data, associated costs, lack of motivation, or poor corporate performance. Experiences from other countries also show that government regulations hardly promote sustainability reporting by companies [17]. There is no such obligation for companies in Cambodia. In high-income countries, sustainability reporting is increasingly becoming an issue of legislation. In middle and low-income countries, however, there is no demand for comprehensive sustainability reporting [2]. In globalised competition, this is likely to become a factor for market competition, at least in the long term, and thus equally imperative for companies in middle and low-income countries.

The distribution of companies reporting on sustainability by sector shows that the financial sector accounts for the largest share of the total. This can probably be explained by the awareness of this sector since CSR and sustainability reporting are of interest to financial markets, investments and, thus, also to financial analysts and institutional investors [7]. The large share of the tourism and leisure sector can best be explained by the desire to attract international guests and, therefore, to communicate the efforts as part of the marketing strategy. Its strong growth in recent years can probably explain the increasing reporting of the telecommunications sector.

The GRI framework are the most widely used reporting standard in the world. MNEs with branches or suppliers in Cambodia usually conduct international reporting, which is usually general and does not specifically address activities in Cambodia. The data could probably contribute little to the increase in knowledge since it is usually not clear who and where the concrete suppliers are companies. Therefore, they were not analysed in detail. Nevertheless, it is reasonable to conclude that the results described and the comparison with other countries are at least generally reliable and can indicate a particular trend.

\section{CONCLUSION}

This study aimed to present and analyse the current situation of sustainability reporting in Cambodia to determine whether and in what way sustainable development and its reporting is a concern of Cambodian companies. The primary data basis for the study was the GRI Sustainability 
Disclosure Database. The scientific citation and publication databases do not contain any publications on the subject. The results of the internet research could identify hardly any additional companies, but the data supported the findings from the analysis of the GRI Sustainability Disclosure Database.

The government of Cambodia is consistently pursuing a strategy of sustainable development in the further development of the country. Companies play an important role in the sustainable development of a country. CSR is a relatively new concept in Cambodia. However, there is no national standard for CSR or sustainability reporting for companies in Cambodia, yet companies are involved as stakeholders in the country's development strategy and are made to comply with it. The majority of Cambodian companies base their sustainability reporting on the internationally recognised and widespread GRI framework.

The analysis of the GRI Sustainability Disclosure Database showed that sustainability reporting by companies in Cambodia had increased continuously over the last ten years. The largest share is accounted for by companies in the financial sector, followed by the tourism and leisure sector and the telecommunications sector. The companies in the manufacturing sector, most of which are suppliers, do not appear to have sustainability reporting. In terms of company size, it is mainly large companies that carry out sustainability reporting. What is surprising, however, is that SMEs is increasingly disclosing and communicating its commitment to sustainable development. MNEs, on the other hand, only started doing so a few years ago and still make up the smallest share.

In comparison with the other ASEAN countries, in terms of sustainability reporting, in relation to GDP (PPP), Cambodia is the leader. Thus, it can be said that considering Cambodia's enormous and rapid development to date, the consistent strategy towards sustainable development pursued by the government and especially in relation to current economic performance, Cambodia today could be seen as a hidden champion of sustainability reporting by ASEAN countries and can thus also serve as a role model for other developing countries.

\section{REFERENCES}

1. Royal Government of Cambodia. (2019). Cambodia's Voluntary National Review 2019 on the Implementation of the 2030 Agenda for Sustainable Development. http://mop.gov.kh/. Retrieved November 1, 2019, from http://mop.gov.kh/DocumentEN/Cambodia VNR Publishing-HLPF.pdf

2. UNDESA. (2007). Sustainable Development Innovation Briefs: CSR and Developing Countries What scope for government action? United Nations Department of Economic and Social Affairs. Retrieved November 1, 2019, from https://sustainabledevelopment.un.org/content/ documents/no1.pdf

3. World Bank. (2019). World Development Indicators. The World Bank. Retrieved November $\quad 1, \quad 2019, \quad$ from http://datatopics.worldbank.org/world-development-indicators/

4. Sonja, M. (2009). Die wirtschaftliche Entwicklung Kambodschas in Zeiten der globalen Krise. Konrad-Adenauer-Stiftung e.V. Retrieved November 1, 2019, from https://www.kas.de/documents/252038/ 253252/7_dokument_dok_pdf_17340_1.pdf

5. UNDP. (2018). Human Development Indices and Indicators: 2018 Statistical Update - Cambodia. United Nations Development Programme. Retrieved November 1, 2019, from http://hdr.undp.org/ sites/all/themes/hdr_theme/country-notes/KHM.pdf
6. Chhabara, R. (2008). Increasing Cambodia's Competitiveness Through Corporate Social Responsibility: A SWOT Analysis of CSR in Cambodia. CSRWorks International. Retrieved November 1, 2019, from http://www.csrworks.com/images/CSR-SWOT\%20Report.pdf

7. Bhandarkar, M., \& Alvarez-Rivero, T. (2007). From supply chains to value chains: A spotlight on CSR. Industrial development for the 21st century: Sustainable development perspectives, 387-411.

8. Bowrey, G., \& Clements, M. (2019). Supply Chain Legitimation through CSR Reporting. Australasian Accounting, Business and Finance Journal, 13(1), 27-43.

9. Marsden, C., \& Andriof, J. (1998). Towards an understanding of corporate citizenship and how to influence it. Citizenship Studies, 2(2), 329-352.

10. Schwegler, R. (2009). Moralisches Handeln von Unternehmen: Eine Weiterentwicklung des neuen St. Galler Management-Modells und der Ökonomischen Ethik. Springer-Verlag.

11. Smith, N. C. (2003). Corporate Social Responsibility: Whether or How? California Management Review, 45(4), 52-76.

12. Porter, M. E., \& Kramer, M. R. (2006). Strategy and Society: The Link Between Competitive Advantage and Corporate Social Responsibility. Harvard Business Review, 84(12), 78-92.

13. Peloza, J., \& Shang, J. (2011). How can corporate social responsibility activities create value for stakeholders? A systematic review. Journal of the Academy of Marketing Science, 39(1), 117-135.

14. Pérez, F. J., Romeo, M., \& Yepes-Baldó, M. (2018). The corporate social responsibility policies for the inclusion of people with disabilities as predictors of employees' identification, commitment and absenteeism. Anales De Psicología, 34(1), 101-107.

15. Baumann-Pauly, D., Wickert, C., Spence, L. J., \& Scherer, A. G. (2013). Organizing Corporate Social Responsibility in Small and Large Firms: Size Matters. Journal of Business Ethics, 115(4), 693-705.

16. Matten, D., \& Crane, A. (2007). Business Ethics. In the A to $Z$ of Corporate Social Responsibility - A Complete Reference Guide to Concepts, Codes and Organisations. John Wiley.

17. Ali, W., Frynas, J. G., \& Mahmood, Z. (2017). Determinants of corporate social responsibility (CSR) disclosure in developed and developing countries: A literature review. Corporate Social Responsibility and Environmental Management, 24(4), 273-294.

18. European Commission. (2004). ABC of the main instruments of Corporate Social Responsibility. Office for Official Publications of the European Communities.

19. Miethlich, B. (2019). Disability as a Blind Spot in Sustainability Frameworks and Standards. International Journal of Recent Technology and Engineering, 8(4).

20. Blasco, J. L., \& King, A. (2017). The road ahead: the KPMG survey of corporate responsibility reporting 2017. KPMG International. Retrieved November 1, 2019, from https://assets.kpmg/content/dam/kpmg/xx/pdf/ 2017/10/kpmg-survey-of-corporate-responsibility-reporting-2017.pdf

21. GRI. (2019). About GRI. Global Reporting Initiative. Retrieved November 1, 2019, from https://www.globalreporting.org/Information/ about-gri/Pages/default.aspx

22. Moravcikova, K., Stefanikova, L., \& Rypakova, M. (2015). CSR reporting as an important tool of CSR communication. Procedia Economics and finance, 26, 332-338.

23. Koskela, M. (2014). Occupational health and safety in corporate social responsibility reports. Safety Science, 68, 294-308.

24. Sen, S., Bhattacharya, C. B., \& Korschun, D. (2006). The role of corporate social responsibility in strengthening multiple stakeholder relationships: A field experiment. Journal of the Academy of Marketing science, 34(2), 158-166.

25. GRI. (2019). GRI Sustainability Disclosure Database. Global Reporting Initiative. Retrieved November 1, 2019, from https://database.globalreporting.org/

26. IMF. (2019). World Economic and Financial Surveys: World Economic Outlook Database. International Monetary Fund. Retrieved November 1, 2019, from https://www.imf.org/external/pubs/ft/weo/2019/02/ weodata/index.aspx

\section{AUTHORS PROFILE}

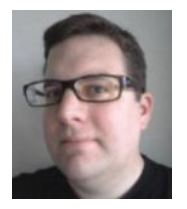

Boris Miethlich is a $\mathrm{PhD}$ student at IIC University of Technology, Cambodia. Before, he studied BSc Industrial Engineering and MSc Business Administration at the Swiss Distance University of Applied Sciences (SDUAS). His research focuses on the business potential of CSR and its exploitation. 